vol. 26 - $n^{\circ} 2 \mid 2010$

Numéro ouvert

\title{
Taking Culture Seriously: The Unexplored Nexus between Migration, Incorporation and Development
}

Convoquer la culture : le lien inexploré entre migration, insertion et développement

Convocar a la cultura. El lazo inexplorado entre migración, incorporación y desarrollo

\section{Peggy Levitt}

\section{OpenEdition}

\section{Journals}

Electronic version

URL: https://journals.openedition.org/remi/5149

DOI: $10.4000 /$ remi.5149

ISSN: $1777-5418$

\section{Publisher}

Université de Poitiers

\section{Printed version}

Date of publication: 1 September 2010

Number of pages: $139-153$

ISBN: 978-2-911627-55-2

ISSN: 0765-0752

\section{Electronic reference}

Peggy Levitt, "Taking Culture Seriously: The Unexplored Nexus between Migration, Incorporation and Development", Revue européenne des migrations internationales [Online], vol. 26 - n² | 2010, Online since 01 September 2013, connection on 14 April 2022. URL: http://journals.openedition.org/remi/ 5149 ; DOl: https://doi.org/10.4000/remi.5149 


\title{
Taking Culture Seriously: the Unexplored Nexus between Migration, Incorporation and Development
}

\author{
Peggy LEVITT*
}

$\mathrm{M}$ ost discussions about the relationship between migration, incorporation, and development suffer from two misguided assumptions. First, they focus too much on the economic at the expense of the socio-cultural. It's as if we just get the money right, all else will follow. Second, they assume that redressing poverty in immigrant communities and alleviating underdevelopment in the communities migrants come from are two separate goals when, in fact, they are often two sides of the same coin. Economic and political incorporation into a new country and economic and social outcomes in the homeland can be strongly linked. It is not possible to achieve one without taking the other into account.

My comments try to redress these weaknesses. First, I propose a transnational optic that redresses the methodological nationalist assumptions that pervades so much of migration scholarship, particularly in the United States. Second, I suggest a way of "bringing culture back in" to debates about the migration-poverty equation and show how thinking culturally elucidates aspects of this nexus that are often obscured. Finally, I conclude with some reflections on the dangers of pinning development hopes solely on migrants.

\section{USING A TRANSNATIONAL OPTIC}

Methodological nationalism is the tendency to accept the nation-state and its boundaries as a given in social analysis (Wimmer and Glick Schiller, 2004). Because much of social science theory equates society with the boundaries of a particular nation state, researchers often take rootedness and incorporation in the nation as the norm, and social identities and practices enacted across state boundaries as the exception. But while nation-states are still extremely important, social life does not obey national boundaries.

* Professor, Dept. of Sociology, Wellesley College and Co-Director, Transnational Studies Initiative, Harvard University; plevitt@wellesley.edu 
Social and religious movements, criminal and professional networks, and governance regimes, to name just a few, regularly operate across borders.

These ostensibly novel transnational phenomena have clear historical analogues - one need only think of colonialism and imperialism, missionary campaigns, anti-slavery and workers' movements, pirating networks, and jazz. Indeed, human social formations and processes have always been trans-border and trans-boundary to varying degrees. Cross-border forms and processes are the focus of a burgeoning yet fragmented body of scholarship though researchers working in these areas do not always see themselves as part of the same conversation. They study transnational corporations, religions, or social movements in isolation from each other without bringing to light the forms and patterns these domains share. Because, as it turns out, transnational economic forms and processes have a lot in common with their political and religious counterparts, a new optic, which asks a different set of questions based on different ontological and epistemological assumptions, is called for.

Transnational Studies (TS) advances the claim that the global, regional, national and the local can be analyzed through transnational methodological, theoretical, and epistemological lenses (Khagram and Levitt, 2007). In contrast to traditional perspectives, which see the transnational as happening somewhere between the national and the global, TS proposes another option. What are assumed to be bounded and bordered social units are understood as transnationally constituted, embedded and influenced social arenas that interact with one another. The world consists of multiple sets of dynamically overlapping and interacting transnational social fields that create and shape seemingly bordered and bounded structures, actors, and processes.

Thus, the terms "transnational," "transnationalism" and "transnationality" are partly misnomers, in that they imply that the only things we care about are dynamics across or beyond nations, states, or within the (nation-) state system. They mean something else. A transnational optic or gaze begins with a world without borders, empirically examines the boundaries and borders that emerge at particular historical junctures, and explores their relationship to unbounded arenas and processes. It does not take the appropriate spatial unit of analysis for granted. In other words, TS interrogates the territorial breadth and scope of any social phenomena without prior assumptions. It does not privilege the global or the local but holds these layers of social experience, and all others in between, in conversation with each other, examining how these multiple sites and layers interact with and inform one another.

Transnational migration studies begin by identifying the parameters of the appropriate social field. Social fields are sets of multiple interlocking networks of social relationships through which ideas, practices, and resources are unequally exchanged, organized, and transformed (Levitt and Glick Schiller, 2004). They are multi-dimensional, encompassing structured interactions of differing forms, depths, and breadths. National social fields are those that stay within national boundaries while transnational social fields connect actors, through direct and indirect relations across borders. 
Any study, whether of an ethnic or religious community or organization in the Midwestern United States or in Singapore must start out by asking how these actors and institutions are influenced by other actors and institutions around the world. It must empirically assess the extent to which the objects are embedded in multi-layered, multi-sited spaces and evaluate the influence of ideas and objects from near and far. It may be that there is little connection - that the congregation or group functions largely on its own. It may also be, however, that the rituals enacted in a storefront church or the projects undertaken by a hometown association are strongly shaped by people and institutional arrangements across the globe. Without looking at who and what are circulating in and around these seemingly rooted and isolated individuals and groups, the analysis comes up short. Without interrogating the potential importance of global institutional norms and values packages, the analysis will also be incomplete.

What does a transnational optic bring to light that studying migration within the boundaries of the nation-state obscures? First, it elucidates how much the experiences of migrants and non-migrants are connected because, although separated by physical distance, these two groups often occupy the same socio-political space. Because goods, people, money, and social remittances circulate regularly, even individuals who never move are influenced by values and practices from far away. They have a clear picture of what life is like for their migrant friends and relatives, even if this image is quite distorted. The religious, civic, and political organizations in which they participate also assume new forms and functions in response to the cross-border lives of their constituencies.

Second, the social fields within which migration takes place are multi-layered as well as multi-sited. The horizontal ties between a particular sending community and the urban neighborhood where migrants settle are important. But these connections must also be understood within the context of the broader, vertical ties in which they arise. To fully understand the lives of Salvadorans in Los Angeles, we have to take the role of the Salvadoran and U.S. governments and the Salvadoran and U.S. Catholic churches into account. Similarly, understanding the religious lives of Turks in Germany requires looking beyond the connections between specific congregations at home and abroad and placing them in the context of the thick, multi-layered web of regional and national connections that also link these countries and other countries around the world.

Finally, seeing migrants and nonmigrants as occupying the same social space also drives home the changing meaning of incorporation. The immigrant experience is not a linear, irreversible journey from one membership to another. Rather, migrants pivot back and forth between sending, receiving and other orientations at different stages of their lives. The more their lives are grounded in legal, health care and pension systems on both sides of the border, the more likely it is that migrants will continue to live transnational lives. Increasing numbers of newcomers will not fully assimilate or remain entirely focused on their homelands but will craft some combination of the two in ways that ebb and flow across the life course. Their lives will be enabled and constrained by multiple cultural repertoires and institutions. Social mobility and inclusion in a new place, therefore, is strongly connected to social status and inclusion in the old one. 


\section{IMAGES OF CULTURE}

Most debates about migration and development privilege the economic at the expense of the social. Migrant remittances and philanthropic transfers amount to $\$ 338$ billion a year globally - nearly twice the amount of official development assistance (World Bank, 2009). International aid agencies and governments are hard at work designing policies to tap into and purposefully channel these resources (Wilmaladharma et al., 2004). Against this backdrop, it is not surprising that many scholars and policymakers hail remittances as the next development panacea.

But economics is not the whole story. Culture permeates all aspects of the development enterprise - as a challenge and an opportunity. Migrants carry ideas, practices, and narratives and these enable mobility and different forms of membership and belonging. Culture also strongly influences how development goals are established, the policies put in place to achieve them, and how successfully they are achieved. By privileging the economic, researchers and policymakers overlook an important potential aid and/or barrier to project success (Rao and Woolcock, 2007). When scholars and policymakers acknowledge that culture strongly influences socioeconomic outcomes, they tend to treat it as contextual (a dependent variable, i.e. "America's culture of individualism") or as a characteristic (a sub-unit of some other independent variable, e.g. a belief system within an organization that values collective decision-making). By treating culture as a residual value, or by suggesting that it cannot be studied scientifically, we also risk promoting policies that fail to take into account key aspects of the social worlds we hope to improve (Lamont and Small, 2008). What is actually meant by "culture" merits further attention.

Bringing culture more centrally into migration debates requires not only looking at the "migration of culture" (or religion, or ideas, or artistic practices) but also seeing migration as a cultural act. Because migrants' identities and actions are rich in cultural and social meaning, focusing solely on social networks, positions, or activities comes up short. It is not when or that these practices or identities may be cultural but rather that they are inherently cultural. Cognitive maps and cultural categories are constantly defined and re-defined, which is why culture, as well as structure and technology, matter.

\section{MOVING BEYOND CULTURE AS PRODUCT}

Once we recognize that culture plays an integral role in poverty, incorporation, and underdevelopment, where should we look for it and what forms does it take? How can it be used to gain insights into the migration-development nexus puzzle and what are the costs and benefits implicit in such an approach?

Most policies treat culture as a product - a material and concrete object, like a dance, a piece of music, folk art, or the tradition of storytelling that is transformed, reinvented, or threatened by migration. Culture is either seen as something to be revived and preserved, resuscitated and reinforced - an unconditional good to be protected at all costs. Or it is seen as impeding integration or development. Particular groups have negative cultural traits that prevent them from learning to work hard, trust strangers, 
or govern effectively - the alleged prerequisites for modernity and progress (Harrison and Huntington 2000, Banfield 1958). Or culture is seen as a tool of empowerment. By allowing a group to express its culture, it can stake its claim to a place in a new society.

This view is problematic for several reasons. First, cultural products are not set in stone. They are not preserved in tact nor completely transformed when people move. The power relations surrounding the expression and representation of particular cultural artifacts also change. Who should decide what dance or song represents some allegedly homogeneous group? Even more misguided is the mistaken understanding of culture as a discrete, packageable whole that can be lifted out and analyzed separately from social relations.

A more fruitful approach treats culture as a dimension of all social relations and forms and, therefore, affects all aspects of immigrant incorporation and sending-community development. Rather than seeing culture solely as a product, it is also a process. When people participate in and perform cultural representations, they also create and reinvent them. Cultural events are sites of boundary work during which communities affirm who they are and enact the boundaries of belonging for their members and for the outside world.

For instance, male patrones or benefactors generally sponsor the Fiesta Patronal or Patrón Saint's Day celebrations in Latin America, a role that comes with great respect and responsibility. In fact, for emigrants to remain citizens of many indigenous Mexican communities, they still have to fulfill certain collective obligations even though they no longer live there. But migration has changed all that. Since so many community members live in the United States, there are too few men to sponsor the celebration. As a result, some communities rewrite the rules, allowing people living abroad to be patrones, who then delegate the day-to-day responsibilities to a non-migrant relative or friend. Or the community allows younger men or women to assume ancillary roles with significant responsibility. By so doing, it signals that its boundaries have expanded to include people living in the United States. It has invented new long-distance ways for people to fulfill their citizenship obligations because membership without residence is not only a possibility but a necessity.

The Fiesta Patronal is a performance for outsiders as well as insiders. New kinds of communities are also created through cultural performances (Besserer et al., 2005). La Hora Mixteca, a program on Radio Bilingue, a station serving indigenous people in Mexico and in the southwestern United States helped create a pan-indigenous community. When listeners heard programming in their own language for the first time, they felt part of the Mexican nation in ways they had not experienced before. By hearing their shared indigeneity broadcast back to them, they also felt a sense of belonging to a pan-ethnic community encompassing members in Mexico and the United States. Listening also reinforced generational ties because family members, whether in Mexico or in California, could listen 'together' (NATC Report, 2004).

The Fiesta Patronal is also a site where gender norms are redefined. Women are allowed and, in some cases, required to assume roles they were previously excluded from. 
They gain access to power and decision-making circles that had been off limits to them in the past. Furthermore, when migrants return to live or visit, they bring back different ways of managing gender and family relations with them, shaped by their experiences living abroad. Smith (2005) writes of the tensions around gender that arise between young second generation Mexican American men and women when they visit their ancestral villages. What is considered acceptable behavior in New York is deemed inappropriate in Mexico. The brother who never thought twice about his sister going out alone in Manhattan feels he is responsible for regulating her behavior back in Mexico. Norms compete and individuals and communities must find ways to manage if not resolve that conflict.

Some migrants want to be the benefactor of the Patrón Saint Day celebration because they want to give back to their community. Others seek the position as a platform from which to display their enhanced status. They spend so much money that sponsoring the festival is no longer affordable to most non-migrants. As each new patrón hosts an even more luxurious celebration, villagers' already inflated consumption aspirations grow even greater. What native sons and daughters must do to signal their loyalty is beyond what most residents (migrant or not) feel they can or should be able to afford. Their worth is measured by their financial contributions rather than by their moral authority or leadership skills. Yet no one seems willing or able to stop this vicious cycle. Toning down the celebration would suggest that the community prospered less than it has led itself to believe or that migration's rewards do not always outweigh the sacrifices it entails.

Moreover, migration forces communities to revisit their narratives about progress and success --- about what the goals of development and incorporation should be. Since migrants generally make more money than non-migrants, they tend to influence agenda setting more. Their motives for contributing to the community and what they hope to achieve through their contributions grow increasingly separate from people who stay behind. Migrants see their community as a place to vacation, retire, and eventually die while non-migrants see it as a place where they still need jobs and health care. Non-migrants members want to build funeral homes while non-migrant members want to build schools. A parallel debate emerges vis a vis community activism in the country of settlement. While some community members argue for a shift in focus to social and political integration in the country of settlement, others fear this will detract from efforts to help people back home.

Culture is also a regime of norms, power, and status that enables and constrains behavior (Appadurai, 2004). Meanings, symbols and narratives make cultural production possible but also constrain it because the repertoires people use only contain certain items. The terms of recognition and possibility underlying these regimes have to be altered for fundamental change to occur.

For example, some migrants send remittances to friends and family members as a form of social insurance. They choose strategically which connections to emphasize and which to let slide based on what they anticipate their future needs will be (Bryceson and Vuorela, 2002). How acceptable it is for someone to make these kinds of choices is shaped by the normative regimes in play. In some social contexts, individuals feel and are considered incomplete by others if they are not part of a family or group. They cannot make 
decisions without thinking first about their family's reputation. A similar kind of transnational moral economy influences young people's marriage options, lifestyle choices, occupational possibilities, and the level of resources they have to pursue their life plans. Because social embeddedness is so thick and dense, individuals cannot make self-interested choices without the risk of being ostracized by the group.

Take the example of Moreno, a middle-aged man who came back from the United States to his Dominican village to open a small cement factory, making him one of the village's few employers. His neighbors strongly criticized him when he opted to hire the best workers rather than his relatives and friends. A Pakistani entrepreneur, who started a software company in Boston, faced similar issues. His friends and family in Karachi also had lots to say when he decided not to hire "every distant acquaintance from home who showed up on his doorstep looking for a job." How much each man could alter their economic behavior was culturally constrained and fraught with social consequences.

Changes in gender relations are another arena in which cultural regimes both enable and constrain the possible. In Karachi, most women do not go to the mosque to pray. In Boston, they not only pray at the mosque but also actively run its cultural and educational activities. Because the mosque functions as a socio-cultural center and is structured according to U.S. law, women serve as teachers, administrators, and trusteesroles which would have been unheard of in the past. The cultural repertoire shifts but only so far. Women pray with men but not alongside them.

Sommer (2005) and her colleagues conceptualize culture as agency. Art, she argues, has the capacity to 'interrupt' or 'to unblock procedures mired in habitual abuses or indifference in order to get those practices back on track.' Art unsettles habits and regimes through 'defamiliarization' or the surprise that is elicited by a new artistic technique or encounter. Cultural engagement nudges actors outside of their comfort zones and habitual ways of doing and thinking that can lead to positive, purposeful social change. According to Sommer, we are all cultural agents, referring to the small shifts in perspective and practice that turn artists, teachers, and religious and community leaders into catalysts of collective change. It's not a question of whether we exercise agency but how selfconsciously we do so, to what end, and with what effect.

Throughout the world, creative arenas have long been a vehicle for agency. Without the "Teatro Campesino," many labor organizers who worked for César Chávez argued that there would have been no United Farm Workers' Union. On the flatbeds of pick-up trucks parked just beyond the limit of a landholder's property, loudspeakers called pickers to watch and join the plays that poked fun at bosses and celebrated workers' solidarity. At the Gujarati Social Forum in India, a sexuality rights NGO launched its campaign with a street play (also a familiar venue) about hijras - castrated males who consider themselves to be women deep inside - who lived in the region (Levitt and Merry, 2009). Many consider the places where hijras live to be pure and sites of justice. The narrative revealed to audience members that accepting same-sex relationships was not merely a western import but something with deep Indian roots. Facilitators presented new ideas about same-sex relationships using English words that they then explained with familiar elements such as paintings, dances, and storytelling. 
But culture is also about profit. We should not forget the underlying economic interests that shape cultural enactments nor the economic benefits that flow from them. The markets engendered by transnational migration build and expand upon already-well-developed ethnic and nostalgia markets in many immigrant communities. A successful fiesta patronal requires costumes, instruments, souvenirs, and food. Even places get marketed. One of the fastest growing religious shrines in Mexico is Santa Ana de Guadalupe in Jalisco State, believed to be the birthplace of Mexico's Patrón Saint of Migrants, St. Toribio. It was not economic development that transformed this former backwater into a thriving community, but the many tourists who make pilgrimages there each year (Levitt, 2007).

The potential for profit is not lost on the state. Governments produce their own versions of tradition for public consumption and worldwide dissemination, which often differ significantly from the community's account. The Chilena, originally considered a dance of the poor, became legitimate and profitable after it was appropriated by the Mexican government (Revilla López, 2000). The state, for its part, pushed a commercial, tourist spectacle, displaying the splendor of Mexico to its urban residents and foreigners. In contrast, Grupos chilenos and technobandas used the form to invoke a strong sense of belonging among Mixtecos, whether they were born in the community or not. Because Chilenas do not consist of a fixed set of elements, musicians could incorporate new instruments and rhythms, producing an alternative national self-representation outside the reach of the state.

Finally, an important piece of understanding the relationship between culture, development, and incorporation is cultural circulation. How do ideas and practices move in ways that shape and are shaped by the migration experience?

In The Transnational Villagers (2001), I coined the term social remittances to call attention to the fact that, in addition to money, migrants also export ideas and behaviors back to their sending communities. I observed at least four types of social remittances - norms, practices, identities and social capital circulating in the Dominican village of Miraflores that I studied. Social remittance exchanges occur when migrants return to live in or visit their communities of origin; when non-migrants visit those in the receiving country; or through exchanges of letters, videos, cassettes, e-mails, and telephone calls. They are distinct from, but often reinforce and are reinforced by, other forms of global cultural circulation.

While the idea of social remittances has gained some traction in the literature, it is not without critics. They argue that the "social" should also include the "cultural" and that social remittances do not just move in one direction. They also caution against seeing social remittances as always positive. I agree. However, to study how social remittances travel and to evaluate their impact, researchers have to look in one place at one point in time. While this methodological imperative can unintentionally suggest that ideas and practices travel only one way, they, in fact, circulate continuously. What migrants bring and continue to receive from their homelands affects their experiences in the countries where they settle. This, in turn, affects what they send back to non-migrants who either disregard or adopt these ideas and behaviors, transforming them in the process, and eventually re-remitting them back to migrants who adopt and transform them once again. 
My colleague Deepak Lamba-Nieves (2010) and I are revisiting the idea of social remittances by conducting new fieldwork in Miraflores. Our findings reveal (1): the strong connection between people's experiences prior to migration and their civic and political engagement in the countries where they move, (2) the distinction between individual and collective social remittances, and (3) the ways in which social remittances scale out to other domains of practice and scale up to other levels of social and political organization.

We found that the individuals we are studying bring with them a strong commitment to work for the collective good. Many had a great deal of experience participating in social, religious, and political organizations before they migrated. They also brought technical and organizing skills that aided their efforts in the United States. Their experiences abroad challenged and expanded how they did things and why they did them. The types of projects they took on and how they implemented them reflected these changes. As groups in the U.S. matured, assumed the lion's share of responsibility for fund raising, and learned how to work transnationally, they took the lead in proposing ventures that were consonant with their new "vision" of what hometown development entails.

Projects like a sports complex, a fire station and an ambulance are examples of the chapters' growing organizational capacity. They reflect migrants' heightened concern with safety and health and their assumption that living in a developed community means living somewhere where these services are part and parcel of what good governments do. They foment "state-society synergies" or collaborations between social actors and government entities that bridge public-private divides (Evans, 1996). These ideas scale out as residents apply them to other domains of practice. Not only do they expect the government to share the cost of public safety but to partner with them in providing education and health. They also scale up, as community members not only change their expectations of local government but of provincial and national governments as well.

Clearly, not everything migrants export back to their homelands is positive. Many people fear that the flow of ideas from the United States devalues family, deifies consumerism, and encourages sexual permissiveness. They hold migrants responsible for the rising popularity of fundamentalist Islam and Hinduism in India and Pakistan. In small villages throughout Latin America and Asia, a generation is being raised on remittances. These young people dream of making a home in the United States or Europe rather than in their countries of origin. Rather than going to school or trying to find a job, they spend their days waiting for their monthly check or for the magic day when their visa finally arrives. It is not worth it to them to work in a factory or on a farm (if such work is available) because their parents send money anyway. Not only do their skills and discipline waste away while they wait, but the economic base of their communities also deteriorates.

Social remittances involve interpersonal exchanges of ideas, skills, and know-how. They are local-level instances of global cultural creation and dissemination. But there is another level of world culture and global values packages against which migration takes place and which shapes migrants' discourses about themselves and the policy debate about them (Boli and Thomas 1996). World culture is also a cultural repository from which people imagine belonging and membership in today's world and the kinds of institutional arrangements and social contracts which arise in response. 
Over the last four years, my colleague Sally Merry and I studied the localization of global ideas about women's human rights ideas and practices in four locations: Beijing, China, Baroda, India, Lima, Peru, and New York City, USA. ${ }^{1}$ In each site, we compared two or three non-governmental organizations (NGOs) working to implement women's human rights to see how they translated global concepts into local terms. One group was usually more domestically oriented and connected, while the other was connected to more international networks. We asked what women's human rights look like in the day-to-day work of these organizations and what explains why organizations translate these concepts in different ways. Our research not only sheds light on how things circulate and why certain things are adopted or not, but also reveals how the travels of particular notions about woman as subjects combine with local understandings.

We found that there are several kinds of global values package that are critical to the spread of ideas about women's rights. A neo-liberal package, promoting democracy, capitalism, human rights, the rule of law, transparency and accountability and gender equity that is spread by institutions like The World Bank and The Ford Foundation is perhaps most familiar. A fundamentalist religious package based on gender complementarity, tradition, conservatism, and authority, that is spread by religious networks like Tablighi Jamaat is a second example. A third global values package is an anti-globalism package, based on anti-consumerism and materialism, simplification, green lifestyles, fair trade, and environmental consciousness.

Vernacularization occurs when these global ideas are appropriated and customized to fit local contexts. There are three types of vernacularization: The first relies on the imaginative space created by women's human rights. It uses the momentum and power provided by the backdrop of this discourse to advance a cause but does not use the words or practices directly. The second type vernacularizes ideas. It stretches the boundary of issues considered by women's groups by using the language of human rights to tackle new issues. The third type of vernacularization involves using the core concepts of women's human rights, articulating them in locally appropriate ways, and putting them into practice.

In Peru, China, the United States, and India, we found that each of the NGOs we studied combined global ideas about women's rights with existing social justice and national women's movements to produce different articulations of what rights are and how they should be used. Human rights connected to social work in China; Liberation Theology in Peru; Gandhian practice and socialism in India; and Lesbian, Gay, Bisexual, and Transgender (LGBT) and people of color activism in the United States. Through this process, NGOs in each site constituted assemblages, or collections of discourses, practices, and technologies of activism. The contents of these assemblages varied considerably by location despite their shared reliance on a human rights frame. In Peru, ideas about human rights attached to the practice of creating communal kitchens and Catholic Liberation Theology base communities. In China, they connected to the government-backed All China Women's Federation and to universities. In India, they drew on caste panchayats

1 This research was a collaboration with Liu Meng at the Department of Social Work, National Women's University in Beijing, N. Rajaram at the Department of Sociology, Maharaja Sayajirao University in Baroda, India, and M. Rosa Alayza at the Escuela de Graduados, Pontífica Universidad Católica del Perú in Lima, Peru. 
and the village panchayat system while in the USA, they attached to the battered women's movement, using the language of human rights documentation and of being a survivor.

These ideas and models of rights, identity, and pluralism circulate widely. They are both a response to transnational migration and they enable it. They provide the words and symbols with which the general public and policymakers can imagine and justify a world where people live lives across borders. They shift the social imaginary in ways that make possible a conversation about a social contract fulfilled beyond national boundaries if not the beginnings of its implementation. They provide the building blocks for problem solving outside the nation state container-for seeing immigrant poverty and sending community development as two sides of the same coin.

\section{CONCLUSION}

This article proposes a transnational optic for understanding migration and a way of thinking about culture so that it can be integrated more centrally and creatively into migration policy, projects, and research. I want to bring into focus how the migration of ideas and practices, both locally and globally, informs and is informed by the migration of people. How do circulating ideas and practices enable migration and expand the boundaries of belonging? What happens when cultural elements in motion encounter each other? As more and more people live lives across borders, where will the cultural elements come from that expand the social imaginary beyond the nation-state?

I hope that my comments help jumpstart a more truly interdisciplinary conversation. There is an important lesson here. Socially and culturally oriented researchers have to make compelling arguments to people outside our disciplines. We must be able to specify how cultural dynamics scale up to influence larger economic and social processes of production and reproduction. How, for example, do culturally driven changes in gender relations scale up to influence changes in reproductive health and labor market incorporation? How do long-standing migrant networks between India and East Africa influence the "race for Africa" between India and China today? How does a weak culture of volunteerism influence the emergence of diasporic philanthropy in general?

But more quantitatively oriented researchers must also reach beyond their intellectual comfort zones. They can't continue to dismiss culture as residual or impossible to operationalize. Culture is part of the development diagnosis and an integral part of its solution (Rao and Walton 2004). This means that generalizable best practices are difficult to come by because each challenge requires a unique local solution. Cultural resonance also implies operating according to different time horizons. Short-term rewards are unlikely to lead to lasting change or to allow for learning by doing. They create unrealistic expectations, which set up projects to fail before they begin. The work of translation goes both ways.

There is also a clear divide between scholars most concerned about what happens to immigrants once they arrive somewhere new and those most concerned about what happens where they come from. This is a false dichotomy. These processes were never 
disconnected and they are certainly not today. Continuing to speak about them and organize research around them separately is counterproductive. It reifies an artificial separation that does not reflect migrants' lives and it prevents us from responding creatively to the challenges they face.

Finally, that migrants make major contributions to national development is not lost on sending-country governments or institutions like the International Monetary Fund or the World Bank. But designing development strategies around the promise of migrants' future contributions is dangerous. It is like holding the victim responsible for the problem he or she is the victim of. It allows states to continue to pursue policies that cause migration and to avoid confronting it economic and social roots. It also disproportionately burdens migrants by saddling them with overwhelming financial and social responsibilities and by holding them hostage to their community and nation's future. This is not just unfair-it also commits migrants to a standard they may be unable or uninterested in upholding in the future.

\section{References}

APPADURAI Arjun (2004) The Capacity to Aspire: Culture and the Terms of Recognition, in Vijayendra Rao and Michael Walton Eds., Culture and Public Action: A Cross-Disciplinary Dialogue on Development Policy, Palo Alto, CA, Stanford University Press, pp. 59-84.

BANFIELD Edward C. (1958) The Moral Basis of a Backward Society, New York, The Free Press. BESSERER Federico et al. (2005) Informe de Investigacion \#1 Etnografía Transnacional de Santa María Tindú, Curcuito Oaxaca, Sub-circuito Mixteca, Unpublished Manuscript.

BOLI J. and THOMAS G. M. (1999) Constructing world culture: international nongovernmental organizations since 1875, Palo Alto, CA, Stanford University Press.

BRYCESON Deborah and VUORELA Ulla (2002) The Transnational Family: New European Frontiers and Global Network, Oxford and New York, Berg.

EVANS Peter (1996) Government Action, Social Capital and Development: Reviewing the Evidence on Synergy, World Development, 24 (6), pp. 1 119-1 132.

HARRISON Lawrence and HUNTINGTON Samuel (Eds) (2000) Culture Matters - How Values Shape Human Progress, New York, Basic Books.

KHAGRAM Sanjeev and LEVITT Peggy (2007) The Transnational Studies Reader, New York, Routledge.

LAMONT Michèle and SMALL Mario L. (2008) How Culture Matters: Enriching Our Understanding of Poverty, in David Harris and Ann Lin Eds., The Colors of Poverty: Why Racial and Ethnic Disparities Persist, New York, Russell Sage, pp. 76-102.

LEVITT Peggy (2007) God Needs No Passport: Transnational Religious Life, New York, The New Press.

LEVITT Peggy (2001) The Transnational Villagers, Berkeley, University of California Press.

LEVITT Peggy and GLICK SCHILLER Nina (2004) Transnational Perspectives on Migration: Conceptualizing Simultaneity, International Migration Review, 38 (145), pp. 595-629.

LEVITT Peggy and LAMBA-NIEVES Deepak (2010) Social Remittances Reconsidered, Journal of Ethnic and Migration Studies, under review.

LEVITT Peggy and MERRY Sally (2009) Vernacularization on the Ground: Local Uses of Global Women's Rights in Peru, China, India and the United States, Global Networks, 9 (4), pp. 441-61. 
MEYER J., BOLI J. and THOMAS G. (1994) Ontology and Rationalization in the Western Cultural Account, in W.R. Scott, J.W. Meyer and Associates Eds., Institutional Environments and Organizational Structural Complexity, Thousand Oaks, CA: Sage, pp. 7-27.

NORTH AMERICAN TRANSNATIONAL COMMUNITIES (2004) The Cultural Dimension of Transnational Communities Meeting Report, Oaxaca City, Oaxaca Mexico, August 9-10, 2004 , Internal Rockefeller Foundation Document.

RAO Vijayendra and WALTON Michael (2004) Conclusion: Implications of a Cultural Lens for Public Policy and Development Thought, in Vijayendra Rao and Michael Walton Eds., Culture and Public Action: A Cross-Disciplinary Dialogue on Development Policy, Palo Alto, CA, Stanford University Press, pp. 359-72.

RAO Vijayendra and WOOLCOCK Michael (2007) The Disciplinary Monopoly in Development Research at the World Bank, Global Governance, 13, pp. 479-84.

REVILLA LOPEZ Ulises (2000) La chilena mixteca transnacional, Unpublished Master's Thesis, La Universidad Autónoma Metropolitana, Iztapalapa Campus, Mexico, Anthopology Department, $62 \mathrm{p}$.

SMITH Robert (2005) Mexican New York, Berkeley, University of California Press.

SOMMER Doris (2005) Art and Accountability, Unpublished Manuscript.

WIMALADHARMA J. et al. (2004) Remittances: the new development finance, Small enterprise development, 15 , pp. 12-20.

WIMMER Andreas and GLICK SCHILLER Nina (2003) Methodological Nationalism: The Social Sciences and the Study of Migration: An Essay in Historical Epistemology. International Migration Review, 37 (3), pp. 576-610.

WORLD BANK, (2009) Migration and Remittances Factbook, Washington, DC. 


\title{
Taking Culture Seriously: the Unexplored Nexus between Migration, Incorporation and Development
}

\author{
Peggy LEVITT
}

Most discussions about the relationship between migration, incorporation, and development suffer from two misguided assumptions. First, they focus too much on the economic at the expense of the socio-cultural. It's as if we just get the money right, all else will follow. Second, they assume that redressing poverty in immigrant communities and alleviating underdevelopment in the communities migrants come from are two separate goals when, in fact, they are often two sides of the same coin. Economic and political incorporation into a new country and economic and social outcomes in the homeland can be strongly linked. It is not possible to achieve one without taking the other into account. This article tries to redress these weaknesses. First, it proposes a transnational optic that redresses the methodological nationalist assumptions that pervades so much of migration scholarship, particularly in the United States. Second, it suggests a way of "bringing culture back in" to debates about the migration-poverty equation and shows how thinking culturally elucidates aspects of this nexus that are often obscured. Finally, it concludes with some reflections on the dangers of pinning development hopes solely on migrants.

\section{Convoquer la culture : le lien inexploré entre migration, insertion et développement}

\section{Peggy LEVITT}

La plupart des débats à propos de la relation entre la migration, l'insertion et le développement souffrent de deux hypothèses erronées. D'abord, ils se concentrent trop sur la dimension économique aux dépens de la dimension socioculturelle en faisant de l'accès au revenu la principale clef de lecture. Deuxièmement, ils supposent que la réduction de la pauvreté au sein des communautés d'immigrants et le développement des localités d'origine des migrants sont deux objectifs séparés quand, en fait, ils sont souvent les deux faces de la même pièce. L'insertion économique et politique dans un nouveau pays et les incidences socio-économiques dans le pays d'origine peuvent être fortement liées. Il n'est donc pas possible de chercher à saisir l'une de ces dimensions sans prendre l'autre en considération. Cet article essaye de parer ces faiblesses en proposant, d'une part, de privilégier un point de vue transnational pour mieux contrebalancer les positionnements méthodologiques stato-centrés qui imprègnent la recherche sur les migrations, plus particulièrement aux États-Unis. D'autre part, cet article explore une voie possible « en réincorporant la culture » au sein du débat relatif à l'équation entre migration et pauvreté et démontre que l'approche en termes de culture permet d'éclairer différemment certains aspects souvent mal compris de cette relation. Enfin, cet article se conclut par quelques éléments de réflexions sur les risques que comporte l'idée de faire reposer l'espoir de développement seulement sur les migrants. 


\section{Convocar a la cultura. El lazo inexplorado entre migración, incorporación y desarrollo \\ Peggy LEVITT}

La mayoría de los debates sobre la relación entre migración, incorporación y desarrollo sufren de dos hipótesis erróneas. Primero, se concentran demasiado sobre la dimensión económica al detrimento de la dimensión sociocultural, haciendo del acceso a la renta la principal clave de lectura. Después, suponen que la reducción de la pobreza dentro de las comunidades de migrantes y el desarrollo de las localidades de origen de estos migrantes son dos objetivos separados; cuando en realidad se trata a menudo de los dos lados de una misma moneda. La inserción económica y política dentro de un país nuevo y las incidencias socioeconómicas en el país de origen pueden estar íntimamente ligadas. Por eso es imposible tratar de entender a una de estas dimensiones sin tomar en consideración a la otra. Este articulo trata de prevenir contra estas insuficiencias proponiendo de privilegiar un punto de vista transnacional para contrabalancear a los posicionamientos metodológicos centralizados alrededor de los Estados, posicionamientos que impregnan la investigación sobre migraciones, especialmente en los Estados-Unidos. Por otra parte el explora un camino posible, «re-incorporando la cultura» en el debate sobre la ecuación migración y pobreza y demuestra que el enfoque en términos de cultura permite aclarar de manera diferente ciertos aspectos, generalmente mal entendidos de esta relación. Finalmente, este artículo se concluye con algunos elementos de reflexión sobre el riesgo que comporta la idea de hacer pesar solamente sobre las espaldas de los emigrantes. 